\title{
Heterogeneity of Endothelial Cells
}

\section{The Specialized Phenotype of Human High Endothelial Venules Characterized by Suppression Subtractive Hybridization}

\author{
Jean-Philippe Girard, ${ }^{*}$ Espen S. Baekkevold, ${ }^{\dagger}$ \\ Takeshi Yamanaka, ${ }^{\dagger}$ Guttorm Haraldsen, ${ }^{\dagger}$ \\ Per Brandtzaeg, ${ }^{\dagger}$ and François Amalric* \\ From the Institut de Pharmacologie et de Biologie Structurale du \\ CNRS, ${ }^{*}$ Toulouse, France; and the Laboratory for \\ Immunohistochemistry and Immunopathology, Institute of \\ Pathology, University of Oslo, The National Hospital, \\ Oslo, Norway
}

High endothelial venules (HEVs) are specialized postcapillary venules, found in lymphoid organs and chronically inflamed tissues, that support high levels of lymphocyte extravasation from the blood. Molecular characterization of HEV endothelial cells (HEVECs) has been hampered by difficulties in their purification and in vitro maintenance. To overcome these limitations, we developed a strategy combining the use of freshly purified HEVECs $(\sim 98 \%$ positive for the HEV-specific marker MECA-79) and the recently described polymerase chain reaction (PCR)-based cDNA subtraction cloning procedure called suppression subtractive hybridization (SSH). Subtracted probes prepared by SSH from small amounts of total RNA were used to screen a HEVEC cDNA library. This resulted in cloning of 22 cDNAs preferentially expressed in HEVECs, which encode the promiscuous chemokine receptor DARC, mitochondrial components, and matricellular proteins. The latter included hevin, thrombospondin-1, and mac25/IGFBP-rP1, which is a secreted growth factor-binding protein previously found to accumulate specifically in tumor blood vessels. Biochemical and histochemical analysis confirmed the identification of mac25 and DARC as novel markers of the HEVECs. Ultrastructural immunolocalization revealed a noticeable association of mac25 and MECA-79 antigens with microvillous processes near the endothelial cell junctions, suggesting a role for mac25 in the control of lymphocyte emigration. This study shows that PCR-based SSH is useful for cloning of differentially expressed genes in very small samples. (Am J Patbol 1999, 155:2043-2055)
Although all vascular endothelial cells (ECs) share certain common functions, it has become clear that considerable heterogeneity exists both structurally and functionally along the length of the vascular tree and in the microvascular beds of various organs. ${ }^{1-4}$ The structural heterogeneity of ECs is a perfect example of their adaptation to the unique demands of the actual tissue. ECs can form a tight continuous monolayer in organs such as the brain or the lungs, where they perform important barrier functions. Alternatively, they can form a discontinuous layer with intercellular gaps or fenestrae in organs such as kidney, spleen, or bone marrow, where rapid exchange of fluid, particles, and cells takes place. ${ }^{2}$ The heterogeneity of ECs is also apparent at other levels., ${ }^{3,5}$ For instance, several monoclonal antibodies (mAbs) and phage displayed-peptide sequences that distinguish among different types of ECs are available, ${ }^{3,5-7}$ revealing antigenic differences between continuous and sinusoidal ECs, microvascular and large-vessel ECs, as well as brain and lung ECs. ${ }^{8,9}$ However, EC heterogeneity remains largely ill-defined at the molecular level, and very few organspecific EC markers have been described. 2,4 Thus, although differences between arterial and venous ECs have recently been shown to be genetically determined, as revealed by expression of ephrin-B2 and its receptor Eph-B $4{ }^{10}$ the many genes likely to differ in their expression between arteries and veins have not yet been identified.

So far, the two best understood EC phenotypes are those of blood-brain barrier capillaries and high endothelial venules (HEVs). ${ }^{2,11}$ In contrast to the ECs from other vessels, the HEVECs have a plump, almost cuboidal appearance, express specialized ligands for the lymphocyte homing receptor L-selectin, and are able to support

This work was supported by grants from the Centre National de la Recherche Scientifique, Région Midi-Pyrénées; the Fondation de France; the Ligue Nationale contre le Cancer; the Association pour la Recherche sur le Cancer; the Research Council of Norway; and the Norwegian Cancer Society.

Accepted for publication August 5, 1999

Address reprint requests to Dr. Jean-Philippe Girard, Institut de Pharmacologie et de Biologie Structurale du CNRS, 205 Route de Narbonne, 31077 Toulouse, France. E-mail: girard@ipbs.fr. 
extensive lymphocyte extravasion from blood. ${ }^{11-15}$ At the ultrastructural level, HEVECs exhibit a prominent Golgi complex and glycocalix, abundant mitochondria closely associated with rough endoplasmic reticulum, and many ribosomes frequently found in polyribosome clusters, revealing an intense biosynthetic activity generally not observed in ECs from other vessels. ${ }^{16-18}$ The specialized HEVECs also contain many membrane-bound vesicular structures, multivesicular bodies, Weibel-Palade bodies, and a variety of dense bodies, indicating that they are involved in secretion. ${ }^{16-18}$ One of the major metabolic activities of HEVECs is the sulfation of L-selectin counterreceptors. ${ }^{19-23}$ Sulfate residues have been shown to be the key for the recognition of HEV sialomucins GlyCAM-1 and CD34 by L-selectin ${ }^{20}$ and MECA-79, ${ }^{20,21}$ an HEVspecific adhesion-blocking mAb. ${ }^{24,25}$ Genes important for the sulfation of L-selectin ligands in HEVs include the genes encoding PAPS synthetase, ${ }^{22}$ a bifunctional enzyme that catalyzes the synthesis of PAPS (3'-phosphoadenosine-5'-phosphosulfate), the activated sulfate donor used by all sulfotransferases, and $\mathrm{N}$-acetylglucosamine-6-O-sulfotransferase, ${ }^{26}$ which transfers sulfate from PAPS to HEV sialomucins. In addition to sulfated cell adhesion molecules, ${ }^{20,21,27}$ HEVECs express high levels of secreted molecules such as the chemokine SLC/ 6 Ckine, ${ }^{28}$ which activates lymphocyte adhesiveness, and the SPARC-like antiadhesive matricellular protein hevin, ${ }^{29}$ which may facilitate lymphocyte emigration by modulating EC-to-EC and EC-to-matrix adhesion. ${ }^{30}$

Although recent studies have revealed important features of HEVECs, their molecular characterization is still hampered by purification difficulties ${ }^{29}$ and rapid loss of specialized phenotype in vitro. ${ }^{31,32}$ Therefore, it is necessary to use freshly purified HEVECs for molecular studies; however, the low number of cells obtained after purification precludes the use of standard hybridization protocols, which typically require several micrograms of mRNA (mRNA). To overcome these limitations, we applied a recently developed polymerase chain reaction (PCR)-based technique called suppression subtractive hybridization $(\mathrm{SSH})^{33}$ to a low number of highly purified MECA-79-positive HEVECs. Subtracted probes, generated by SSH from $1 \mu \mathrm{g}$ of total RNA, were then used to screen an HEVEC cDNA library by differential hybridization. This strategy allowed characterization of several human cDNAs preferentially expressed in HEVECs, including those encoding the promiscuous chemokine receptor DARC and the extracellular matrix-associated proteins hevin, thrombospondin-1 (TSP-1), and mac25/ IGFBP-rP1. DARC, which we found expressed in human tonsil HEVs in a pattern almost identical to that of the MECA-79 antigens, may provide a chemokine scaffold important for lymphocyte emigration through HEVs. Immunohistochemical staining also confirmed the abundant and preferential expression of TSP-1 and mac25 in HEVs in situ. mac25 is a secreted growth factor-binding protein that has previously been found to accumulate in tumor blood vessels but not in those in normal tissues. ${ }^{34,35}$ Our results suggest that mac25 is also a good marker of small blood vessels (HEVs and capillaries) in lymphoid tissue. In addition, ultrastructural immunolocalization revealed a noticeable association of mac25 with MECA-79-positive microvillous structures located near the interendothelial junctions of HEVs. Taken together, our results identify mac25/IGFBP-rP1 and DARC as novel markers of HEVECs and suggest that these molecules may contribute to the multistep process of lymphocyte emigration through HEVs.

\section{Materials and Methods}

\section{Suppression Subtractive Hybridization}

Total RNA was isolated from first-passage human umbilical vein ECs (HUVECs) (PromoCell, Heidelberg, Germany) or highly purified HEVECs, cultured for 2 days (HEVEC-2D) ${ }^{32}$ with an RNeasy kit (Qiagen, Courtaboeuf, France). To obtain sufficient amounts of double-stranded cDNA for a subtraction experiment, both HEVEC and HUVEC cDNAs were preamplified with the SMART PCR cDNA synthesis kit (Clontech, Palo Alto, CA), an efficient method for the generation of high-quality cDNA from small amounts of total RNA. HEVEC CDNA, synthesized from $1 \mu \mathrm{g}$ of total RNA with Advantage KlenTaq polymerase (20 PCR cycles; Clontech), was subtracted against HUVEC cDNA, using the PCR-select cDNA subtraction kit (Clontech) according to the manufacturer's protocol. The PCR-Select kit is based on the use of the SSH technique. ${ }^{33}$ Briefly, PCR-generated HEVEC and HUVEC cDNAs were digested with Rsal to generate blunt-ended small cDNA fragments (size distribution, 0.2-2 kb) that are suitable for adaptor ligation and optimal for subtractive hybridization. For the first hybridization, the mixtures of HEVEC and HUVEC cDNAs were incubated for 8 hours at $68^{\circ} \mathrm{C}$. For the second hybridization excess competitor cDNA was added directly to the pooled mix of the two previous hybridizations and allowed to incubate at $68^{\circ} \mathrm{C}$ for 18 hours. Differentially expressed cDNAs were then selectively amplified by two successive PCR (27 cycles) and nested PCR (12 cycles) reactions. The uncloned HEVEC HUVEC $_{\text {H }}$ or HUVEC HEVEC $_{\text {HEV }}$ subtracted mixtures were then used as hybridization probes for differential screening of a HEVEC cDNA library. The efficiency of subtraction was analyzed by PCR with two oligonucleotide primers specific for human PAPS synthetase, ${ }^{22}$ PAPS-7, 5'-GGTGATGGAACAAGGAGATTGGCTG-3', and PAPS-8, 5'-GAGTGACTGGGT-TAACAGCCTAAGC-3'.

\section{Differential Hybridization Screening with Subtracted Probes}

A $\lambda$ ZAPII-HEVEC cDNA library, previously generated from freshly purified human tonsil HEV-derived endothelial cells, ${ }^{29}$ was used for screening with the subtracted probes. Primary screening of this library was performed by differential hybridization, using as the plus probe the mixture of subtracted HEVEC HUVEC $_{\text {CDNAs and as the }}$

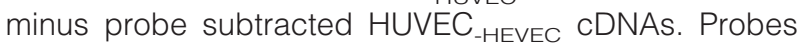
were ${ }^{32}$ P-labeled by random priming (Gibco-BRL, Grand Island, NY). Duplicate filter lifts (Amersham, Les Ulis, France) from five plates, each containing 3000 plaques, 
were hybridized at $42^{\circ} \mathrm{C}$ overnight in $50 \%$ formamide, $5 \times$ Denhardt, $0.5 \%$ sodium dodecyl sulfate (SDS), $5 \times$ standard saline citrate (SSC), $50 \mu \mathrm{g} / \mathrm{ml}$ tRNA, and $50 \mu \mathrm{g} / \mathrm{ml}$ herring sperm DNA. The membranes were then washed with $1 \times$ SSC, $0.1 \%$ SDS at room temperature $(2 \times 15$ minutes $)$ and $0.1 \times$ SSC, $0.1 \%$ SDS at $55^{\circ} \mathrm{C}(2 \times 15$ minutes). Plaques from differential hybridizing clones were picked and the corresponding pBluescript II SKphagemids rescued by in vivo excision, using Exassist helper phage (Stratagene, La Jolla, CA). For the secondary screening, inserts were released from the plasmid DNA by digestion with restriction enzymes EcoRI and Xhol, separated on a $1 \%$ agarose gel, stained with ethidium bromide, and transferred to nylon membranes (Hybond-N+; Amersham). Duplicate filters were then screened by differential hybridization with ${ }^{32} \mathrm{P}$-labeled HEVEC $_{\text {HUVEC }}$ or HUVEC-HEVEC subtracted CDNA probes, using the same hybridization conditions as for the primary screening. The differentially hybridizing cDNA clones were further characterized by DNA sequencing, virtual Northern blots, and immunohistochemistry.

\section{DNA Sequencing and Sequence Analysis}

The 22 cDNA clones identified with the HEVEC-HUVEC subtracted probe were sequenced on both $5^{\prime}$ and $3^{\prime}$ ends, using a Sequenase DNA sequencing kit with Sequenase version 2.0 T7 DNA polymerase (Amersham, Paris, France). The program BLASTP ${ }^{36}$ was used to compare sequences of the isolated clones with all sequences present in the National Center for Biotechnology Information (NCBI) nonredundant nucleic acid database. Protein sequences of human mac25/IGFBP-rP1 and human, mouse, and rat $\mathrm{SC} 1 /$ hevin were aligned using the program CLUSTAL W. ${ }^{37}$

\section{Virtual Northern Blot Analysis}

The SMART PCR cDNA synthesis kit (Clontech) was used to generate high yields of full-length cDNAs from $1 \mu \mathrm{g}$ total RNA of placenta, HUVECs, or cultured human tonsil HEVECs that were 98\% MECA-79-positive on day 2 (HEVEC-2D) and $<1 \%$ MECA-79-positive by day 8 (HEVEC-8D). ${ }^{32}$ For virtual Northern blots, placenta, HUVEC, and HEVEC cDNAs (0.2 $\mu \mathrm{g}$ per lane) were electrophoresed on a $1 \%$ agarose gel, transferred onto nylon membranes (Hybond-N+; Amersham, Paris, France), and hybridized with ${ }^{32}$ P-labeled cDNA probes at $42^{\circ} \mathrm{C}$ overnight in 50\% formamide, $5 \times$ Denhardt's solution, $5 \times$ SSC, $0.5 \%$ SDS, $50 \mu \mathrm{g} / \mathrm{ml}$ tRNA, and $50 \mu \mathrm{g} / \mathrm{ml}$ herring sperm DNA. The membranes were then washed with $1 \times$ SSC, $0.1 \%$ SDS at room temperature $(2 \times 15$ minutes $)$ and $65^{\circ} \mathrm{C}(2 \times 15$ minutes $)$ and exposed, with two intensifying screens, to Kodak XAR- 5 film at $-70^{\circ} \mathrm{C}$ for $2-72$ hours, depending on the probe. Purified EcoRI-Xhol fragments corresponding to the different cDNAs were ${ }^{32} \mathrm{P}$ labeled by random priming (Gibco-BRL) and used as probes in the Northern blots. The human $\beta$-actin control probe was obtained from Clontech.

\section{Immunohistochemistry}

Tissue specimens of fresh palatine tonsils were embedded in OCT (TissueTek, Elkhart, IN) and then snap-frozen in liquid nitrogen. Cryosections $(4 \mu \mathrm{m})$ were air-dried overnight and acetone fixed ( 10 minutes, $22^{\circ} \mathrm{C}$ ).

The tissue sections were first incubated with a mixture of mAb MECA-79 (rat IgM, 1/30; kindly provided by E. C. Butcher, Stanford, CA) and mAb p10 against human thrombospondin-1 (mouse IgG1, 1/50; Immunotech, Marseille, France) or mAb Fy6 against DARC (mouse IgG1, 1/30; kindly provided by R. Horuk, Richmond, CA) (60 minutes at $22^{\circ} \mathrm{C}$ ), followed by a mixture of Cy3-conjugated goat anti-rat IgM (1/100; Jackson ImmunoResearch Laboratories, West Grove, PA) and biotinylated goat anti-mouse IgG1 (1/200; Southern Biotechnology, Birmingham, AL) $\left(60\right.$ minutes at $\left.22^{\circ} \mathrm{C}\right)$. The final step consisted of a streptavidin-Cy2 conjugate (1/1000; Amersham, Aylesbury, UK) (30 minutes at $\left.22^{\circ} \mathrm{C}\right)$. In another protocol, MECA-79 was combined with rabbit polyclonal antibodies against human mac25/IGFBP-rP1 (1/500; kindly provided by R. G. Rosenfeld, Portland, OR) (60 minutes at $22^{\circ} \mathrm{C}$ ), followed by a mixture of Cy3-conjugated goat anti-rat IgM and biotinylated goat anti-rabbit IgG (1/80; Vector Laboratories, Burlingame, CA) (60 minutes at $22^{\circ} \mathrm{C}$ ) and finally Cy2-conjugated streptavidin (30 minutes at $22^{\circ} \mathrm{C}$ ).

Negative controls were human tonsillar tissue sections incubated with irrelevant isotype- and concentrationmatched mAbs. Microscopy was performed with a Nikon E-800 fluorescence microscope (Nikon Corp., Tokyo, Japan) equipped with a CCD camera (Hamamatsu Photonics Norden AB, Kista, Sweden).

\section{Electron Microscopy}

Tissue specimens of fresh palatine tonsils for immunoelectron microscopy were fixed in $1 \%$ paraformaldehyde in $0.1 \mathrm{~mol} / \mathrm{L}$ phosphate buffer (30 minutes at $22^{\circ} \mathrm{C}$ ). Putative HEV-rich areas were cut into rectangular strips measuring $2 \times 2 \times 5 \mathrm{~mm}$ and fixed by immersion fixation in $1 \%$ paraformaldehyde and $0.5 \%$ glutaraldehyde (4 hours at $4^{\circ} \mathrm{C}$ ). Samples were then dehydrated through an ethanol series with progressive lowering of temperature to $-20^{\circ} \mathrm{C}$ and embedded in Unicryl (BioCell, Cardiff, Wales). Ultrathin sections were cut at $60-80 \mathrm{~nm}$ and mounted on formval-coated 300-mesh nickel grids (Agar Scientific, Stansted, UK). Material fixed in 2\% glutaraldehyde and $1 \% \mathrm{OsO}_{4}$ followed by epoxy resin embedding was used for morphological assessment.

Sections were absorbed in blocking buffer (phosphate-buffered saline with $0.8 \%$ bovine serum albumin, $0.1 \%$ fish gelatin, and $5 \%$ fetal calf serum), incubated with rabbit polyclonal antibodies against human mac25/ IGFBP-rP1 (1/100) or von Willebrand factor (1/160; Dakopatts, Glostrup, Denmark) (overnight at $4^{\circ} \mathrm{C}$ ), followed by $5 \mathrm{~nm}$ gold-conjugated goat anti-rabbit IgG (1/50; Amersham) (90 minutes at $\left.22^{\circ} \mathrm{C}\right)$. In another protocol, sections were incubated with MECA-79 (1/10) (overnight at $4^{\circ} \mathrm{C}$ ), followed by biotinylated sheep anti-rat Ig (1/80; Amer- 
sham) (90 minutes at $22^{\circ} \mathrm{C}$ ), and finally $5 \mathrm{~nm}$ gold-conjugated streptavidin (1/80; Amersham) (60 minutes at $22^{\circ} \mathrm{C}$ ). Sections were silver-enhanced (6 minutes) and contrasted with uranylacetate and $\mathrm{Pb}$-citrate. Specimens were examined with a JEM-1200EX electron microscope (JEOL, Tokyo, Japan). Control sections were incubated with irrelevant isotype- and concentration-matched primary antibodies.

\section{Western Blotting}

Conditioned supernatants $(50 \mu \mathrm{l})$ from primary cultures of HUVECs or HEVECs, grown for 5 days (the MECA-79+ period), were fractionated by sodium dodecyl sulfatepolyacrylamide gel electrophoresis (SDS-PAGE) (10\%) under nonreducing conditions. Detection was performed with rabbit polyclonal antibodies against human mac25/ IGFBP-rP1 (1/1500) (incubated overnight at $4^{\circ} \mathrm{C}$ ), followed by an enhanced chemiluminescence kit (Amersham).

\section{Results}

\section{Suppression Subtractive Hybridization Cloning of Human HEV Genes}

A major advantage of SSH over standard differential or subtractive hybridization methods is that it is fully compatible with a PCR-based preamplification method allowing synthesis of high-quality double-stranded cDNA from small amounts of total RNA. Starting with a limited amount of total RNA $(1 \mu \mathrm{g})$ from highly purified HEVECs $(98 \%$ positive for the HEV-specific marker MECA-79), we thus generated high-yields of double-stranded HEVEC cDNAs suitable for subtracted probe generation (Figure 1A). The quality of these HEVEC cDNAs was checked by hybridization with ${ }^{32} \mathrm{P}$-labeled $\mathrm{CDNA}$ probes corresponding to human PAPS synthetase or E-selectin genes. As expected, ${ }^{22}$ a major band at $2.5 \mathrm{~kb}$ was detected with the PAPS synthetase probe in addition to a less intense signal at $2.3 \mathrm{~kb}$ (Figure 1A, lane 1). With the E-selectin probe, two major signals at $2.8 \mathrm{~kb}$ and $3.8 \mathrm{~kb}$ were found (Figure $1 \mathrm{~A}$, lane 2), corresponding to two of the known E-selectin mRNAs. ${ }^{38}$ These results indicated that full-length cDNAs, for mRNAs of up to $4 \mathrm{~kb}$, were well represented in the HEVEC cDNA population.

To carry out SSH, the HEVEC cDNAs (Figure 1A, lane 3) were first digested with Rsal, a four-base cutting restriction enzyme that generates blunt-ended cDNA fragments suitable for hybridization (Figure 1A, lane 4). The HEVEC cDNA fragments were then divided into two samples, ligated to different adapters, and hybridized with competitor HUVEC cDNA. HUVECs were used as a source of cDNA fragments for the subtraction because they have been extensively studied and represent the best characterized human primary "flat" ECs. ${ }^{4}$ After 8 hours, the two samples were mixed, additional competitor HUVEC cDNA was added, and a second hybridization was performed for 18 hours. Unhybridized differentially expressed HEVEC cDNAs were then selectively ampli-
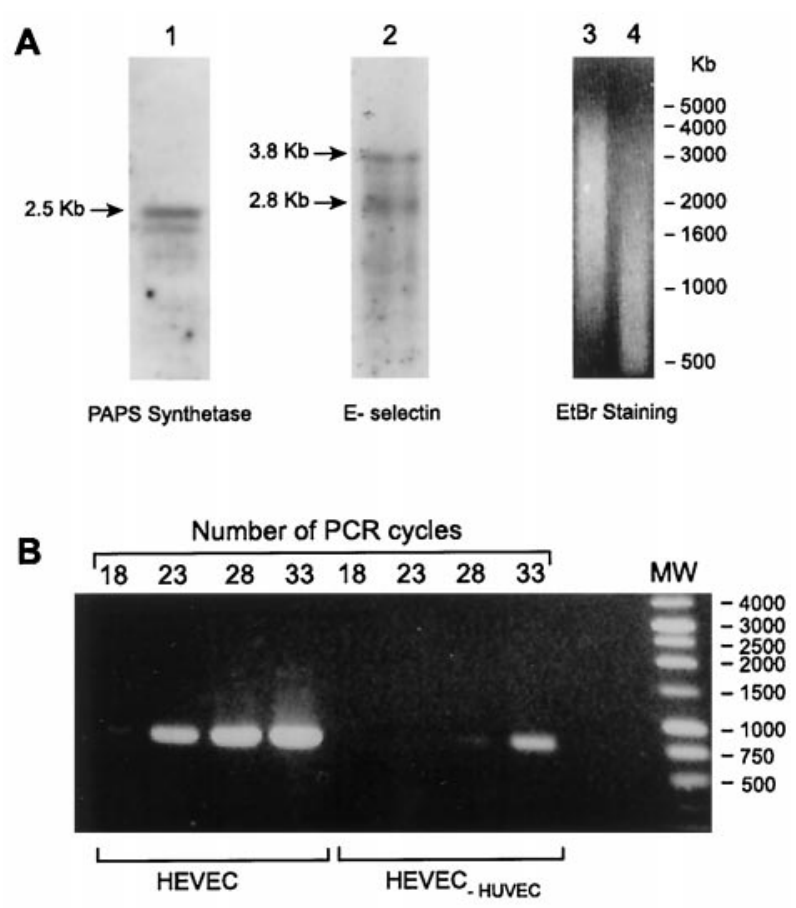

C

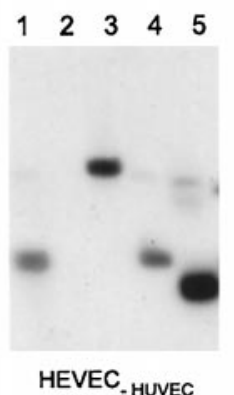

$\begin{array}{lllll}1 & 2 & 3 & 4 & 5\end{array}$

Figure 1. Suppression subtractive hybridization screening. A: PCR-based CDNA synthesis from $1 \mu \mathrm{g}$ HEVEC total RNA. Lanes 1 and 2: Hybridization analysis of HEVEC cDNA integrity with human PAPS synthetase (lane 1) or E-selectin (lane 2) probes. Lanes 3 and 4: Ethidium bromide staining of HEVEC CDNAs before (lane 3) and after (lane 4) Rsa-1 digestion. B: PCR analysis of the efficiency of PAPS synthetase cDNA subtraction. The abundance of PAPS synthetase cDNA fragments in the unsubtracted HEVEC and the subtracted HEVEC $_{\text {-HUVEC }}$ CDNA populations was compared by performing PCR amplification for the indicated number of cycles. C: Southern blot analysis of the isolated cDNAs with HEVEC $_{\text {-HUVEC }}$ and HUVEC -HEVEC $_{\text {sub- }}$ tracted probes. The isolated cDNAs were released from plasmid DNA by digestion with EcoRI and XhoI, separated on a $1 \%$ agarose gel, and transferred onto nylon filters. Duplicate filters were then hybridized with HEVEC $_{\text {-HUVEC }}$ and HUVEC $_{\text {-HEVEC }}$ subtracted probes. Lanes 1, 3, and 4: Differentially expressed cDNAs encoding thrombospondin-1, hevin, and mac25/IGFBP-rP1, respectively. Lane 2: cDNA not detected by the subtracted probes in the secondary screen. Lane 5: cDNA similarly detected with the two probes.

fied by PCR to generate a population of HEVEC-HUVEC subtracted cDNAs. To estimate the efficiency of subtraction, the abundance of a known cDNA was compared before and after subtraction. The mixtures of unsubtracted and subtracted HEVEC cDNAs were analyzed by PCR with primers specific for PAPS synthetase, ${ }^{22}$ which is similarly expressed in HEVECs and HUVECs (J.-P. Girard, unpublished observations). As shown in Figure 
Table 1. Summary of Isolated HEV cDNAs

\begin{tabular}{|c|c|}
\hline $\begin{array}{c}\text { Genes } \\
\text { (no. of clones isolated) }\end{array}$ & $\begin{array}{l}\text { Characteristics } \\
\text { and functions }\end{array}$ \\
\hline \multicolumn{2}{|l|}{ Matricellular proteins } \\
\hline mac25/IGFBP-rP1 & $\begin{array}{l}\text { Secreted growth factor } \\
\text { and heparin binding } \\
\text { protein }\end{array}$ \\
\hline (1) & $\begin{array}{l}\text { Modulates endothelial } \\
\text { cell adhesion to type } \\
\text { IV collagen }\end{array}$ \\
\hline $\begin{array}{l}\text { Hevin } \\
\text { (3) }\end{array}$ & $\begin{array}{l}\text { SPARC-like protein } \\
\text { Modulates endothelial cell } \\
\text { adhesion }\end{array}$ \\
\hline $\begin{array}{l}\text { Thrombospondin-1 } \\
\text { (2) }\end{array}$ & $\begin{array}{l}\text { Angiogenesis inhibitor } \\
\text { Modulates endothelial cell } \\
\text { adhesion }\end{array}$ \\
\hline \multicolumn{2}{|l|}{ Chemokine receptor } \\
\hline DARC & $\begin{array}{l}\text { Promiscuous receptor for } \\
\text { both CC and CXC } \\
\text { chemokines }\end{array}$ \\
\hline (1) & $\begin{array}{l}\text { Receptor for the malaria } \\
\text { parasite Plasmodium } \\
\text { vivax }\end{array}$ \\
\hline \multicolumn{2}{|l|}{ Mitochondrial proteins } \\
\hline Cytochrome $c$ oxidase 1 & $\begin{array}{l}\text { Energy-transducing } \\
\text { membrane protein }\end{array}$ \\
\hline (13) & Involved in ATP synthesis \\
\hline Cytochrome $b$ & $\begin{array}{l}\text { Subunit of complex III of } \\
\text { the respiratory chain }\end{array}$ \\
\hline (2) & Involved in ATP synthesis \\
\hline
\end{tabular}

1B, SSH strongly reduced the abundance of PAPS synthetase cDNA fragments, indicating an efficient subtrac-

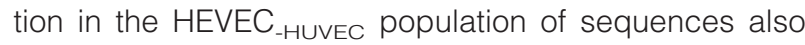
found in the pool of HUVEC cDNAs. A similar strategy was used to generate a population of subtracted HUVEC $_{\text {HEVEC }}$ CDNAs (data not shown). The pools of subtracted HEVEC -HUVEC $_{\text {Or HUVEC }}$-HEVEC CDNAs were then labeled with $\left.{ }^{32} \mathrm{P}\right] \mathrm{dCTP}$ by random priming and used as probes for differential screening of a previously generated HEVEC cDNA library. ${ }^{29}$ Duplicate filter lifts from the HEVEC cDNA phage library (15,000 plaques plated at low density) were screened with the HEVEC. HUVEC or HUVEC -HEVEC $_{\text {probes. Differentially hybridizing }}$ clones from the primary screening (37 clones) were isolated, purified, and used in Southern blot analysis to confirm preferential expression in HEVECs (Figure 1C). Most clones analyzed (22/37) showed a strong positive signal with the HEVEC ize (lanes 3 and 4 ) or gave a very low signal (lane 1) with

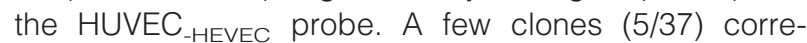
sponded to false positives, being similarly detected with the HEVEC -HUVEC $_{\text {Or }}$ or HUVEC -HEVEC $_{\text {p }}$ probes (lane 5). Finally, the remaining clones picked (10/37) failed to hybridize in the secondary screening with HEVEC -HUVEC $_{\text {Or }}$ HUVEC_-HEVEC probes (lane 2). These clones could represent extremely rare transcripts below the sensitivity limit of our Southern blots. All of the positive clones identified (22 clones) belonged to three different transcript classes (Table 1), which will be discussed in the following sections.

\section{HEVECs Express High Levels of Transcripts Encoding Mitochondrial Proteins}

Sequence analysis of the positive clones isolated by differential hybridization with the HEVEC -HUVEC $_{\text {and }}$ HUVEC $_{\text {HEVEC }}$ subtracted probes revealed that a large number of clones corresponded to mitochondrially encoded genes for cytochrome $b$ (two clones) and subunit I of cytochrome $c$ oxidase (13 clones). To confirm preferential expression of these genes in HEVECs, we used the isolated cDNAs as probes in Northern blot experiments. Because of the limited amount of starting material available (less than $1 \mu \mathrm{g}$ HEVEC total RNA), we performed virtual instead of standard Northern blots. ${ }^{22}$ For this purpose, equal amounts ( $0.2 \mu \mathrm{g}$ per lane) of PCRgenerated unsubtracted full-length cDNAs, prepared from placenta, HUVEC, or HEVEC (cultured for 2 or 8 days; HEVEC-2D or -8D) total RNA, were electrophoresed on an agarose gel, transferred to nylon filters, and hybridized with cDNA probes corresponding to mitochondrial proteins cytochrome $c$ oxidase subunit I (Figure $2 \mathrm{~A}$ ) and cytochrome $b$ (Figure $2 \mathrm{~B}$ ) or control probes encoding ribosomal protein L3 (Figure $2 \mathrm{C}$ ) and $\beta$-actin (Figure 2D). A major 1.6-kb band was detected with the cytochrome $c$ oxidase subunit I probe in 2-day and 8-day samples of HEVECs. The same band was found at significantly lower levels in placenta and was almost undetectable in the HUVEC cDNA population (Figure 2A). This 1.6-kb band corresponds to the size of the full-length cytochrome $c$ oxidase subunit I transcript, which is encoded by the region extending from nucleotides 5327 to 6867 of the consensus human mitochondrial genome. ${ }^{39}$ In addition to the 1.6-kb band, another signal at $2.1 \mathrm{~kb}$ was detected, which might correspond to a precursor species of the 1.6-kb cytochrome $c$ oxidase subunit I transcript. With the cytochrome $b$ probe, a single band of $1.2 \mathrm{~kb}$ was detected at high levels in the HEVEC cDNA population (Figure 2B). This 1.2-kb signal, which corresponds to the size of the cytochrome $b$ mRNA encoded by region $14170-15310$ of the mitochondrial genome, was detected at lower levels in placenta and HUVEC samples, indicating preferential expression of mitochondrial protein cytochrome $b$ in HEVEC.

To demonstrate that the preferential expression of mitochondrial proteins in HEVECs does not result from a general up-regulation of housekeeping genes but rather reflects a specific property of these specialized ECs, which are known to have an intense metabolic activity, we used as a control probe a cDNA corresponding to a housekeeping gene, encoding ribosomal protein L3 (Figure $2 \mathrm{C}$ ). This probe detected a single band of $1.4 \mathrm{~kb}$ in proliferating HUVECs that had been cultured for 2 weeks. A lower but significant signal was detected in the HEVEC 8-day sample (HEVEC 8-D), prepared from HEVECs that had been cultured for 8 days and had started to proliferate, but not in the 2-day sample (HEVEC 2-D), corresponding to resting HEVECs that had been cultured for less than 48 hours. In addition, a very low signal was also found with this ribosomal protein L3 CDNA probe in the placenta tissue sample. These results suggested that 
A

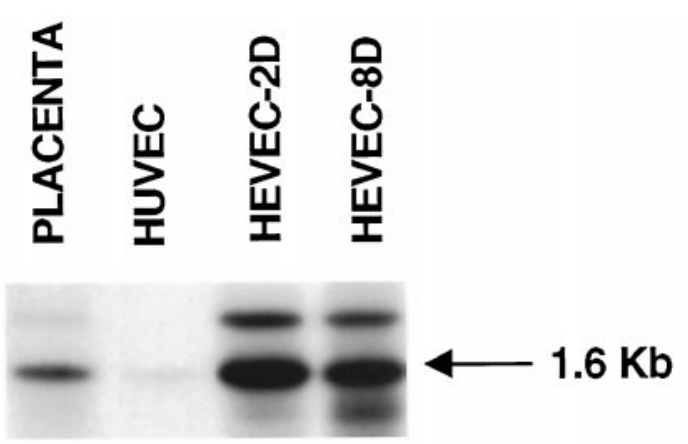

\section{Cytochrome-C oxidase I}
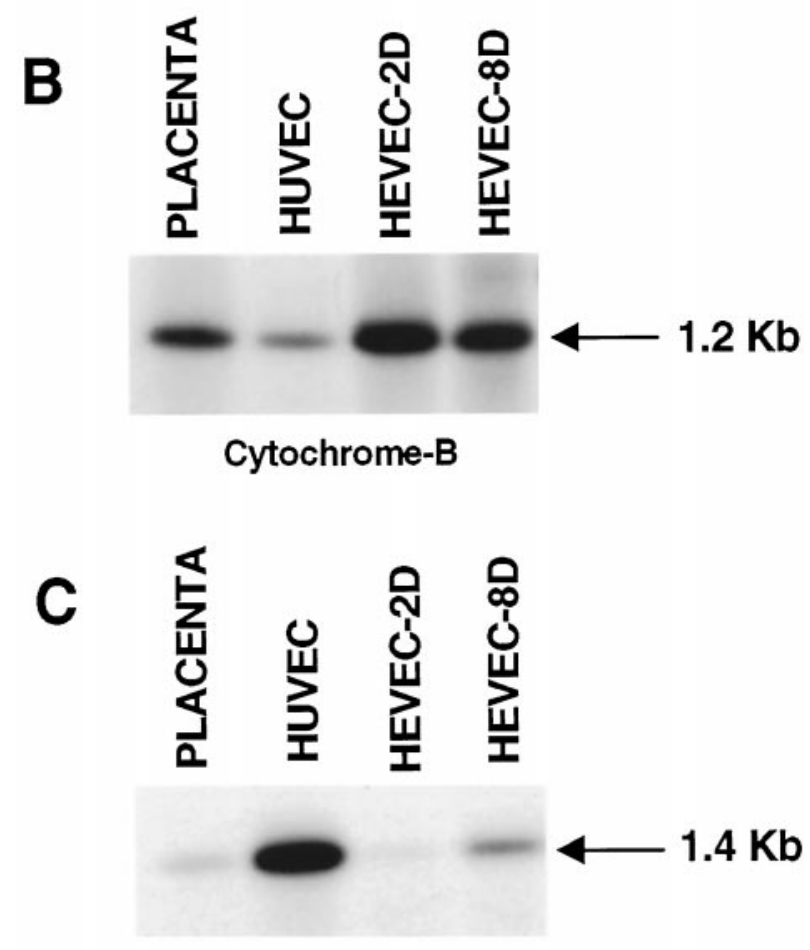

Ribosomal Protein L3

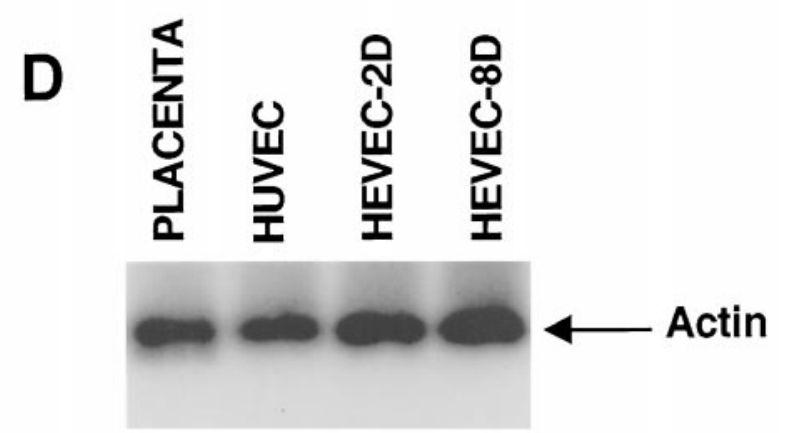

Figure 2. Virtual Northern blot analysis of mitochondrial components, cytochrome $c$ oxidase 1 and cytochrome $b$, ribosomal protein L3, and $\beta$-actin. PCR-generated full-length cDNAs from human placenta, HUVEC and HEVECs cultured in vitro for 2 days (HEVEC-2D; 98\% MECA-79-positive cells) or 8 days (HEVEC-8D; <1\% MECA-79-positive cells) were electrophoresed on a $1 \%$ agarose gel, transferred to nylon filters, and hybridized under high-stringency conditions with ${ }^{32}$ P-labeled cytochrome $c$ oxidase 1 (A), cytochrome $b(\mathbf{B})$, ribosomal protein L3 (C), and $\beta$-actin (D) cDNA probes. expression of this housekeeping ribosomal protein L3 gene correlated with the proliferative state of the different cell types analyzed. In contrast, expression of the mitochondrial proteins cytochrome $c$ oxidase subunit I and cytochrome $b$ did not correlate with the proliferative state but rather appeared to be influenced by the differentiation state of the EC types analyzed. Thus expression of these two mitochondrial proteins was significantly higher in the specialized HEVECs than in the less differentiated HUVECS.

\section{Preferential Expression of Secreted Matricellular Proteins in HEVECS}

The second group of clones isolated in this work corresponded to genes encoding secreted matricellular proteins. Such proteins are regulatory macromolecules that modulate cell-matrix interactions by binding to matrix proteins, cytokines, and proteases as well as to cell surface receptors, but do not contribute significantly to the structural integrity of the extracellular matrix (ECM) ${ }^{40,41}$ cDNA clones corresponding to three different members of this family of matricellular proteins were isolated in our screen (Table 1): thrombospondin-1 (TSP-1; 2 clones), ${ }^{40}$ the anti-adhesive SPARC-like protein hevin (three clones), ${ }^{29,30}$ and mac25/IGFBP-rP1 (one clone), which is a secreted growth factor-binding protein ${ }^{35}$ modulating endothelial cell adhesion to type IV collagen. ${ }^{34}$ Differential screening with the HEVEC-HUVEC or HUVEC-HEVEC subtracted probes revealed that both hevin and mac25/IGFBP-rP1 cDNAs were only detected with the

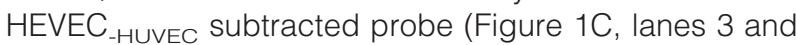
4), whereas the TSP-1 CDNA was also detected, albeit at very low levels, with the HUVEC-HEVEC subtracted probe (Figure 1C, lane 1). These data were consistent with higher expression levels of all three matricellular proteins in the specialized HEVECs than in HUVECs.

These results confirmed our previous studies describing the cloning of hevin as a gene preferentially expressed in HEVECs versus HUVECs ${ }^{29}$ that encodes a secreted protein that accumulates on the basolateral and apical surfaces of HEVECs in vivo. ${ }^{30}$ To confirm preferential expression of TSP-1 in HEVECs in situ, we performed immunostaining of human tonsillar cryosections with $\mathrm{mAb}$ to TSP-1. TSP-1 was found to be abundant in the interfollicular areas but scarce in the follicles (Figure 3A). In the interfollicular areas, the staining was restricted to blood vessels and the reticular meshwork surrounding the follicles. Double labeling with the HEV-specific rat mAb MECA-79, which recognizes sulfated sialomucins mediating $\mathrm{L}$-selectin binding, ${ }^{21}$ revealed that the interfollicular vessels stained for TSP-1 were MECA-79-positive HEVs (Figure 3B). Whereas MECA-79 produced strong staining of both HEVECs and basement membrane, TSP-1 staining was fainter in the vessel wall and was mainly restricted to the basement membrane zone (Figure 3C). This staining pattern of MECA-79-positive HEVs observed with TSP-1 mAb was similar to that observed with mAbs to fibronectin, which also label the basement membrane, but was different from that obtained with 

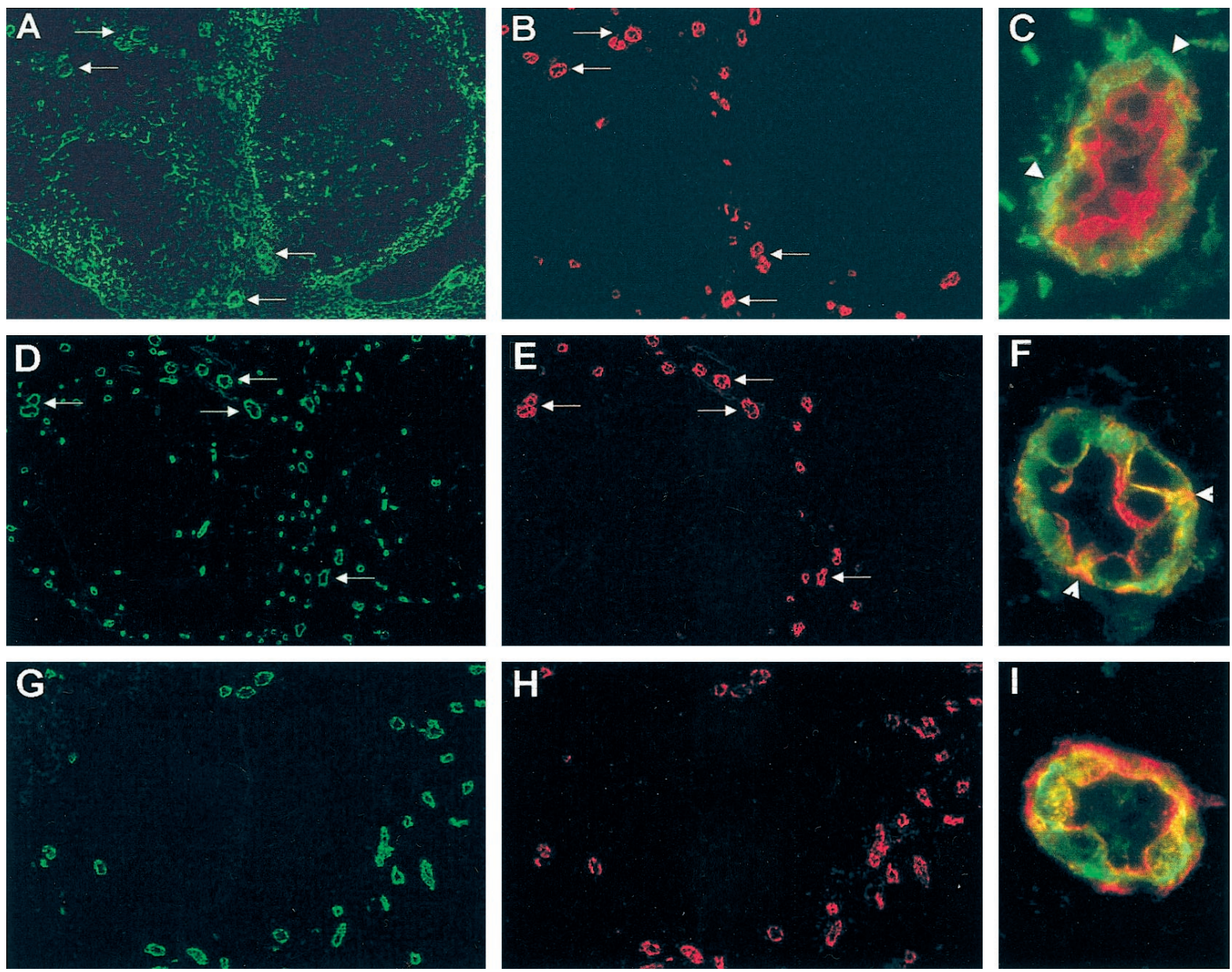

Figure 3. Immunofluorescence staining of MECA-79-positive HEVs with antibodies to thrombospondin-1, mac25/IGFBP-rP1, and DARC. A-C: Antibody to thrombospondin- 1 stains the HEV basal lamina. Cryosections of human tonsils ( $4 \mu \mathrm{m}$, fixed with acetone) were double-stained with mouse MAb P10 against human thrombospondin-1 (A) and HEV-specific rat MAb MECA-79 (B). White arrows indicate HEVs coexpressing MECA-79 antigens and thrombospondin-1. Two-color staining (C) with monoclonal antibodies P10 (green) and MECA-79 (red) reveals that thrombospondin-1 accumulates in the basal lamina of MECA-79-positive HEVs (arrowheads). D-F: Association of the secreted matricellular protein mac25/IGFBP-rP1 with the surface of MECA-79-positive HEVECs in situ. Cryosections of human tonsils were double-stained with rabbit antibodies against human mac25/IGFBP-rP1 (D) and MAb MECA-79 (E). White arrows indicate HEVs coexpressing MECA-79 antigens and mac25. Two-color staining (F) with anti-mac25/IGFBP-rP1 (green) and MECA-79 (red) antibodies reveals that mac25/IGFBP-rP1 is associated with the lumenal and basolateral surfaces of MECA-79-positive HEVECs (arrowheads). G-I: HEV-specific expression of the promiscuous chemokine receptor DARC in human tonsils. Cryosections of human tonsils were double-stained with mouse MAb Fy6 to human DARC (G) and rat MAb MECA-79 (H). Two-color staining (I) with Fy6 (green) and MECA-79 (red) antibodies reveals that DARC is associated with the surface of MECA-79-positive HEVECs. Original magnifications: A, B, D, E, G, H, $\times 100 ; \mathbf{C}, \mathbf{F}, \mathbf{I}, \times 1000$.

antibodies to hevin, which stain basolateral and apical surfaces of HEVECs but not the underlying basement membrane. ${ }^{30}$

\section{The Secreted Matricellular Protein mac25/ IGFBP-rP1 Is Associated with Luminal Microvillous Processes Found in the Junction Area of HEVECs in Situ}

To confirm differential expression of mac25/IGFBP-rP1 between HEVECs and HUVECs, we performed virtual Northern blot and Western blot analyses (Figure 4). Virtual Northern blot analysis of PCR-generated placenta, HUVEC, HEVEC-2D, and HEVEC-8D cDNAs revealed that mac25/IGFBP-rP1 was expressed at higher levels in HEVECs that had been cultured for less than 48 hours (HEVEC-2D) than in HEVECs that had been cultured for 8 days and had started to dedifferentiate (HEVEC-8D) (Figure 4A). This analysis also showed that expression of mac25/IGFBP-rP1 was almost undetectable in the HUVEC or placenta cDNA population (Figure 4A), further emphasizing the preferential expression of mac25/ IGFBP-rP1 in HEVECs. Western blot analysis of supernatants from cultured HEVECs and HUVECs gave similar results; HEVECs were found to secrete high levels of mac25/IGFBP-rP1 (Figure 4B). In contrast, the protein was undetectable in the supernatants of cultured HUVECs.

We concluded from these virtual Northern and Western blot analyses that mac25/IGFBP-rP1 is specifically expressed in specialized HEVECs. To determine whether mac25/IGFBP-rP1 is expressed in vivo in the basement membrane, similarly to TSP-1, or associated with the cell surface of HEVECs, similarly to hevin, we stained human tonsil sections with affinity-purified polyclonal antibodies directed against recombinant mac25/IGFBP-rP1. As 
shown in Figure 3D, this reagent specifically stained numerous small blood vessels found in lymphoid areas of tonsils (follicles and T-cell zones). In contrast, vessels in the nonlymphoid areas of tonsils, salivary gland tissues,
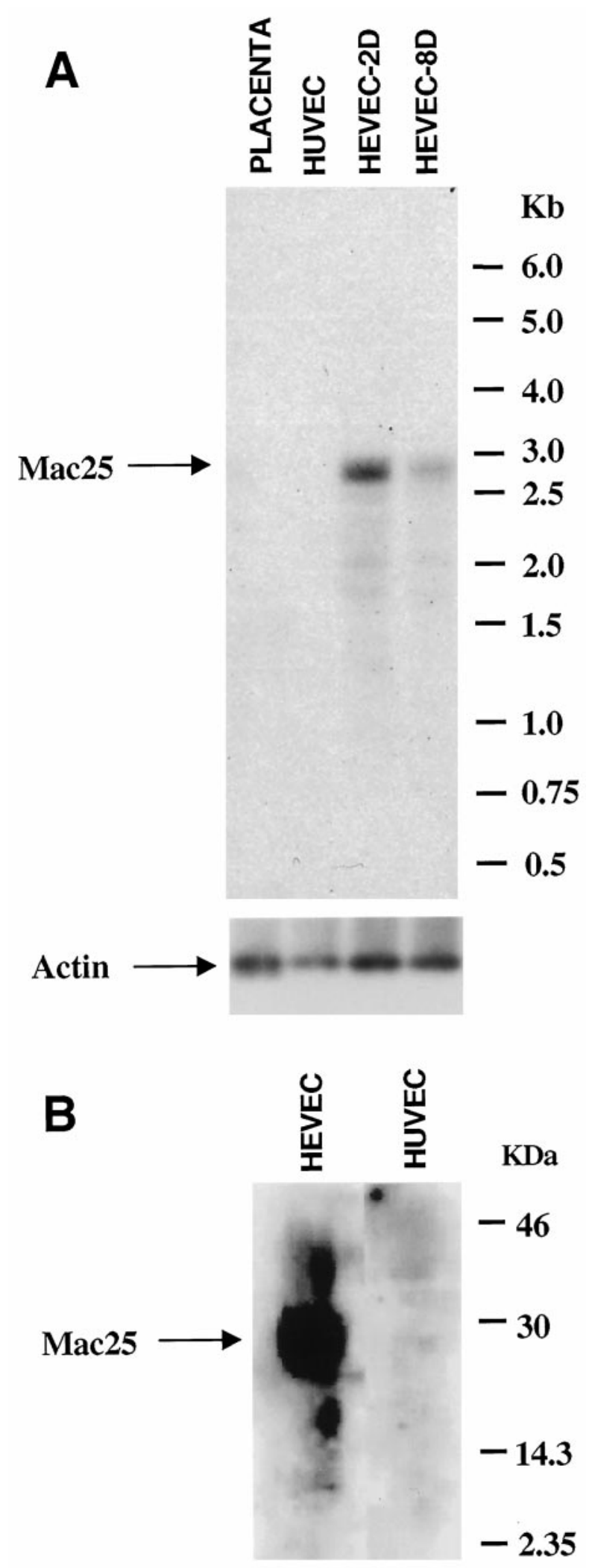

and normal mucosal tissues from mouth and nose were negative (data not shown). The smaller vessels stained with mac25 antibodies corresponded to intrafollicular and interfollicular capillaries, and the larger vessels were identified as postcapillary HEVs by double labeling with MAb MECA-79 (Figure 3E). A high-power view revealed a striking association of mac25/IGFBP-rP1 with the EC surface (Figure 3F). The mac25/IGFBP-rP1 staining was particularly prominent at the luminal and basolateral surfaces in close association with MECA-79 antigens (arrowheads in Figure 3F) but was generally not observed at the underlying basement membrane.

To assess the ultrastructural localization of mac25/ IGFBP-rP1 in HEVs in situ, we performed immunoelectron microscopy on human tonsillar sections. In particular, we focused on the extended luminal microvillous processes near the HEV junctions (Figure 5A), an important site for lymphocyte adhesion and transendothelial traffic. Mac25/ IGFBP-rP1 molecules identified by immunogold particles were markedly enriched on these structures (Figure 5B-C, arrows) compared with luminal or basal membranes (arrowheads). In contrast, application of control polyclonal antibodies directed against human von Willebrand factor ( $v W f$ ) showed a quite different staining pattern, with predominant labeling of Weibel-Palade bodies (Figure 5D). Sections incubated with isotype- and concentration-matched primary antibodies were negative (data not shown). Interestingly, the microvillous processes decorated with mac25 antibodies were also stained with mAb MECA-79, which recognizes sulfated sialomucin counterreceptors for lymphocyte L-selectin (Figure 5, E, F). Therefore, despite the fact that its expression was not strictly HEV-specific, but rather specific for small blood vessels from lymphoid tissues, mac25/ IGFBP-rP1 nevertheless appeared to be a good marker of HEV endothelium, accumulating preferentially on luminal microvillous processes in the junction area of MECA79-positive HEVECs.

\section{The Promiscuous Chemokine Receptor DARC Is Specifically Expressed in HEVECs from Human Tonsils}

An isolated cDNA clone that did not belong to the two other groups of clones encoded the promiscuous human chemokine receptor DARC, ${ }^{42}$ which binds with high affinity to both CC and CXC chemokines. ${ }^{43}$ DARC has previously been shown to be expressed by erythrocytes and postcapillary venules (but not large vessels) in human kidney and spleen, ${ }^{44,45}$ but its expression in

Figure 4. The secreted matricellular protein mac25/IGFBP-rP1 is expressed in HEVECs but not in HUVECs. A: Virtual Northern blot analysis of placenta, HUVEC, HEVEC-2D, and HEVEC-8D cDNAs with a ${ }^{32} \mathrm{P}-$ labeled human mac25/IGFBP-rP1 cDNA probe. The blot was prepared as described in Figure 2 . After hybridization with the mac 25 probe, the blot was deshybridized and reprobed with a human $\beta$-actin cDNA probe. B: Western blot analysis of HEVEC or HUVEC conditioned media with anti-mac25/IGFBP-rP1 rabbit polyclonal antibodies. Molecular weight markers are indicated on the right. 

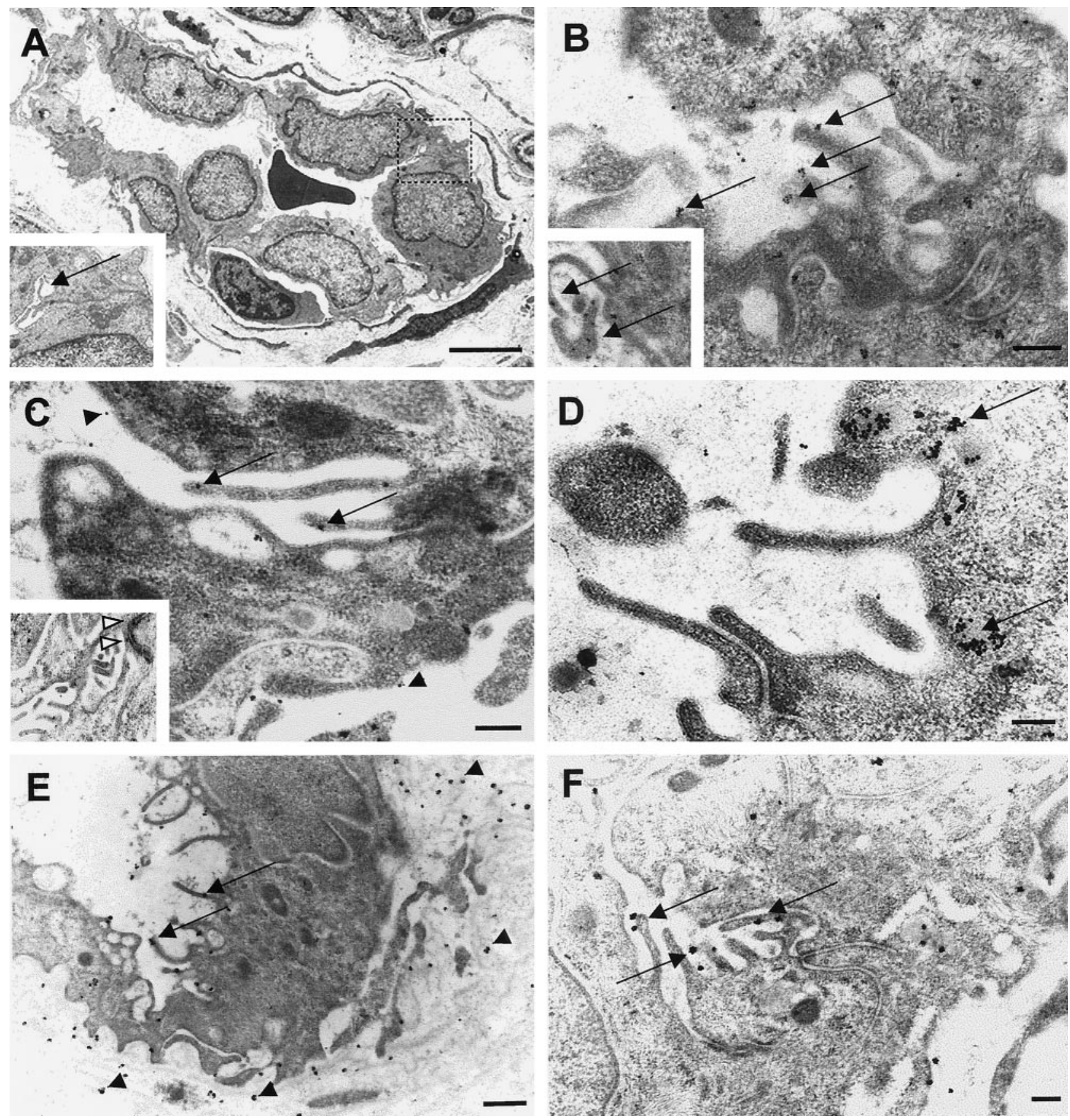

Figure 5. Ultrastructural localization of mac25/IGFBP-rP1 on microvillous processes near endothelial cell junctions. A: Electron micrograph of a tonsillar HEV containing a transmigrating lymphocyte. Inset: Higher magnification view of the lateral junctional area (dotted square) showing luminal microvilli (arrow). B and C: Immunogold staining for mac25/IGFBP-rP1 showed a marked enrichment of gold particles on microvillous structures near the intercellular junctions (arrows) compared with basal and luminal surfaces (B, arrowheads). Insets: Higher magnification views of mac25 localization on villi (B, arrows) and around the adherence junction between ECs (C, open arrowheads). D: Von Willebrand factor was detected in Weibel-Palade bodies beneath the luminal membrane arrows) but was undetectable in microvilli. E and F: MECA-79 antigens were detected on microvilli (arrows) and in the HEV basal lamina (arrowheads). Scale bars: A, $5 \mu \mathrm{m}: \mathbf{E}, 500 \mathrm{~nm} ; \mathbf{B}, \mathbf{C}, \mathbf{D}, \mathbf{F}, 200 \mathrm{~nm}$.

HEV-ECs from human lymph nodes or tonsils has not yet been reported. To confirm preferential expression of DARC in HEVECs, we performed virtual Northern blot and immunohistochemistry. Virtual Northern blot revealed abundant expression of DARC in both HEVEC-2D and HEVEC-8D samples, intermediate levels in placenta, and very low levels in HUVECs (Figure 6). Immunostaining of human tonsillar cryosections with mAb to DARC showed specific labeling of MECA-79-positive HEVs (Figure 3, G-I). No labeling of capillaries or large vessels was detected. DARC staining was clearly associated with the basolateral and apical surfaces of HEVECs (Figure 3I). Together, these data demonstrated that the promiscuous chemokine receptor DARC is a good marker of human tonsillar HEVs, exhibiting an expression pattern in situ almost identical to that of MECA-79 antigens. 

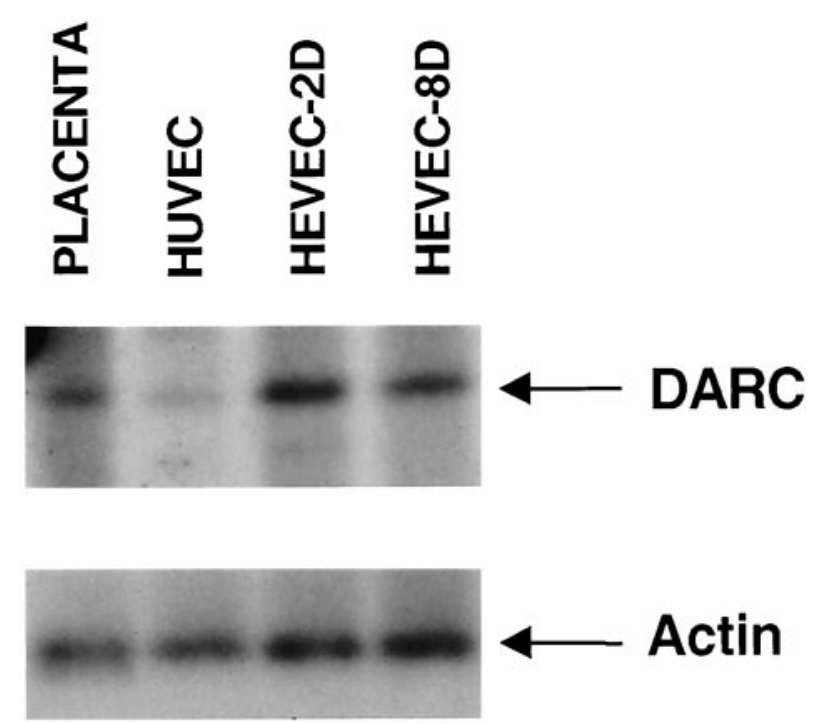

Figure 6. Virtual Northern blot analysis of placenta, HUVEC, HEVEC-2D, and HEVEC-8D cDNAs with a probe encoding promiscuous chemokine receptor DARC. PCR-generated full-length cDNAs from human placenta, HUVEC and HEVECs cultured in vitro for 2 days (HEVEC-2D; 98\% MECA-79-positive cells) or 8 days (HEVEC-8D; <1\% MECA-79-positive cells) were electrophoresed on a $1 \%$ agarose gel, transferred to nylon filters, and hybridized under high-stringency conditions with a ${ }^{32}$ P-labeled human DARC cDNA probe. The blot was standardized for the amount of total cDNA in the indivivual samples with a human $\beta$-actin cDNA probe.

\section{Discussion}

The HEV endothelium represents one of the most striking examples of EC differentiation. ${ }^{11}$ However, despite intensive efforts, the specialized HEVECs remain poorly characterized at the molecular level, and only a few genes preferentially expressed in these cells have been identified. ${ }^{27,29,46}$ Molecular characterization of HEVECs has been hampered by difficulties in their purification and in vitro maintenance. ${ }^{29}$ Most of the problems were due to the fact that HEVECs, like other specialized ECs, are rare and lose their specialized phenotype very rapidly when they are grown in vitro, isolated from their natural tissue environment. ${ }^{31}$ In this study, we solved these problems by applying the PCR-based SSH procedure ${ }^{33}$ to highly purified HEVECs. SSH has been used successfully in several recent studies. ${ }^{47,48}$ The originality of the present work is to show that SSH can also be used when limited amounts of total RNA are available. The coupling of SSH with an efficient PCR-based cDNA synthesis method that works with very small amounts of total RNA (50 ng to 1 $\mu \mathrm{g})$ allowed us to overcome a major limitation of traditional subtractive hybridization techniques that typically require 1-5 $\mu \mathrm{g}$ of poly $\mathrm{A}^{+} \mathrm{RNA}$. Screening of 15,000 plaques from an unsubtracted HEVEC cDNA library, with the subtracted probes generated by SSH, resulted in the cloning of 22 cDNA fragments preferentially expressed in HEVECs. This illustrated the power of this method in identifying in a small number of purified cells genes with restricted expression. Although the technique will have to be optimized, for instance, by using the subtracted probes to screen a subtracted library generated by SSH, our results suggest that this strategy could become the method of choice for cloning of differentially expressed genes from very small samples, such as flow-sorted cells, biopsy specimens, or embryos. In vascular biology, it could make possible the molecular characterization of ECs from other specialized vascular beds, such as blood-brain barrier capillaries, bone marrow sinusoids, tumor blood vessels, and fenestrated endothelium from endocrine glands or the gastrointestinal tract. For instance, the application of our strategy to purified ephrin$\mathrm{B} 2+$ arterial and Eph-B4+ venous ECs ${ }^{10}$ might allow isolation of artery- or vein-specific genes and shed new light on the functional and pathological differences between these two types of vessels.

A major finding in this study is the identification of the promiscuous chemokine receptor DARC and the secreted growth factor-binding protein mac25/IGFBP-rP1 as novel markers of the HEVECs. DARC, first identified on erythrocytes, functions not only as a promiscuous chemokine receptor but also as a receptor for the malaria parasite Plasmodium vivax. ${ }^{42}$ In addition to erythrocytes, DARC has previously been found to be expressed in postcapillary venule ECs from most of the tissues examined. ${ }^{44,45}$ Our finding of HEV-specific expression of DARC in human tonsils (Figure 3G-I) is therefore in complete agreement with previous studies. We found that DARC is abundantly expressed in HEVECs and exhibits an expression pattern in human tonsils almost identical to that of MECA-79 antigens, which makes it one of the best known markers of human HEVs. Similarly to its proposed roles in nonlymphoid tissues postcapillary venules during inflammation, ${ }^{45,49}$ DARC may play two important roles in HEVs during physiological lymphocyte recirculation through lymphoid tissues. First, it could be involved in the transcytosis of lymphoid tissue-derived chemokines through HEVECs in the abluminal-to-luminal direction. ${ }^{45,49}$ Second, it could act as a docking protein to concentrate chemokines at the cell surface for presentation to specific chemokine receptors on lymphocytes. ${ }^{45,49}$ Future studies, such as analysis of DARC "knock out" mice, will be required to determine the relative contribution of DARC to chemokine transcytosis and presentation in HEVs.

The mac25 gene was initially cloned as a gene whose expression is decreased in meningioma cells and tumors relative to normal leptomeningeal cells $\mathrm{s}^{50}$ and subsequently reisolated through differential display as a sequence preferentially expressed in senescent human mammary epithelial cells. ${ }^{51}$ The deduced amino acid sequence of the human mac25 polypeptide shares a $20-25 \%$ identity with human insulin-like growth-factorbinding proteins (IGFBPs), and recombinant mac25 was found to function as an IGF-binding protein. ${ }^{35}$ mac25 was therefore renamed IGFBP-7 and more recently IGFBPrP1. ${ }^{35}$ Two studies have suggested that mac25/IGFBPrP1 is a molecule that plays important roles in vascular biology. Proteins identical to mac25, named prostacyclinstimulating factor (PSF) and tumor-derived adhesion factor (TAF), have been purified for their abilities, respectively, to stimulate prostacyclin production in vascular $\mathrm{ECs}^{52}$ and to contribute to the organization of new capillary vessels in tumor tissues by modulating the interaction of ECs with type IV collagen. ${ }^{34}$ Interestingly, TAF/ 
mac25 was found to accumulate specifically in small blood vessels of tumor tissues, but not in those of normal tissues. ${ }^{34}$ Our findings extend the previous results by showing that mac25 is also expressed in small blood vessels from lymphoid tissues (Figure 3, D-F). Staining with mac25 antibodies revealed a close association of mac25 with the luminal and basolateral surfaces of MECA-79-positive HEVECs. This staining was reminiscent of that obtained with antibodies directed against hevin, which also labeled the luminal and basolateral surfaces of HEVECs, ${ }^{30}$ but was clearly different from immunostaining for thrombospondin or fibronectin that appeared at the HEV basal lamina (Figure 3, A-C). mac25 is likely to be retained on the HEVEC surface by binding to heparan sulfate proteoglycans because TAF/mac25 has been shown, in vitro, to associate with the surface of cultured ECs through heparin-like molecules. ${ }^{34}$ At the ultrastructural level, a noteworthy feature was the association of mac25 molecules with microvillous processes near EC junctions (Figure 5). These microvillous structures constitute the initial points of contact between the endothelium and the adherent lymphocytes and have been shown to harbor chemokines ${ }^{49}$ and adhesion molecules, such as the L-selectin countereceptor CD34 ${ }^{53}$ and L-selectin ligands defined by L-selectin/lgG chime$\mathrm{ra}^{54}$ or HEV-specific mAb MECA-79 (this study). Preferential association of the secreted growth factor binding protein mac25 protein with these microvillous processes on the EC surface makes it a good candidate for a molecule involved in the presentation of adhesion-triggering cytokines to the lymphocytes rolling on, or migrating across, HEV. mac25 contains an amino-terminal domain with homology to IGFBPs that is responsible for low-affinity binding to IGFs. This sequence is followed by a follistatin-like module that has a low but significant homology with the cysteine-rich follistatin-like module of hevin/SC1, which is known to mediate cytokine binding in other proteins (Figure 7). These two modules in Mac25/ IGFBP-rP1 are likely to be involved in growth factor binding and may facilitate the retention of growth factors or chemokines, such as SLC/6Ckine, ${ }^{28}$ on the surface of HEVECs. Finally, the association of mac25 with the basolateral surfaces of HEVECs supports the possibility that mac25 may also play a role in the modulation of HEVEC adhesion to type IV collagen and other ECM proteins of the basal lamina and may influence, either directly or indirectly, the passage of lymphocytes through HEV junctions and the basement membrane. Therefore, mac25 is a secreted growth factor-binding molecule, produced at high levels by the specialized HEV endothelium, that is likely to play very important roles in the biology of HEVECs.

Except for DARC, all of the identified genes preferentially expressed in HEVs encode mitochondrial and matricellular proteins. Preferential expression of these proteins in the HEV endothelium likely reflects two important characteristics of HEVECs: their metabolic specialization and their intense secretory activity. Biosynthetic and secretory activities of HEVs associated with lymphocyte recruitment probably require high levels of ATP synthesis. For instance, a major metabolic activity of the HEV
A

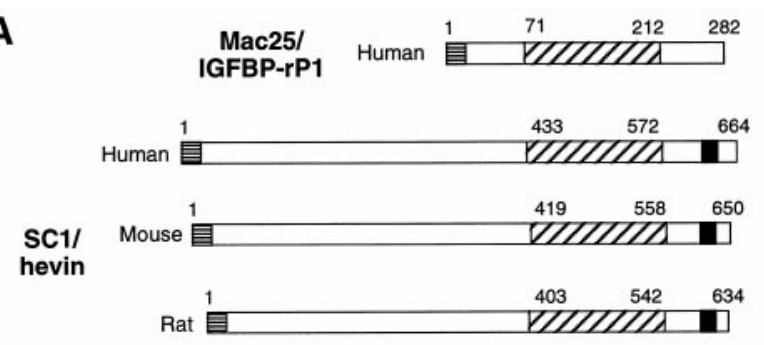

B
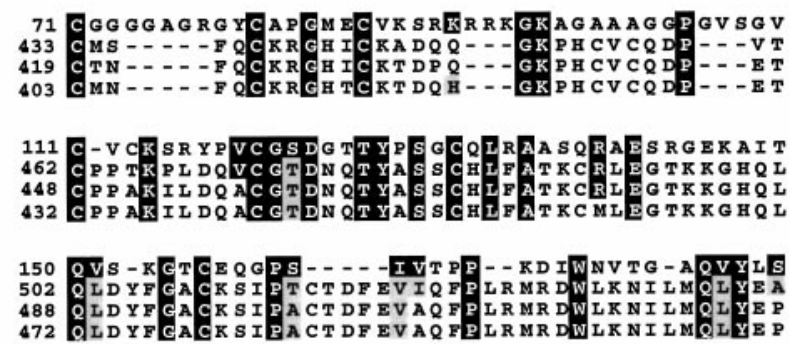

181 CEVIGIPTPVLIWTKVRRGYGVRTELIPGD

542 NSEHAGYLNEKQRNKVKKIYLDEKR- - LLAGD
528 NPKHGGYLNEKORSK VKKIYLDEKR- LLAGD

528 NPKHGGYLNEKQRSKVKKIYLDEKR-- LLAGD
512 NPKHGGYLNEKQRSEVKKIYLDEKR--LLAGD

Figure 7. Comparison of human mac25/IGFBP-rP1 amino acid sequence with human, rat, and mouse hevin/SC1 sequences. A: Schematic representation of mac25/IGFBP-rP1 and hevin/SC1 proteins. The number of amino acids of each protein is indicated. Horizontal hatched lines, signal peptide; diagonal hatched lines, cysteine-rich domain including a follistatin-like module; black box, EF hand calcium-binding domain. B: Amino acid sequence alignment of the cysteine-rich domains of human mac25/IGFBP-rP1 and human, mouse, and rat hevin/SC1. Residues identical between the four sequences are colored in black, those conserved in gray. Dashed lines represent gaps introduced to align sequences.

endothelium that is related to lymphocyte traffic is the selective incorporation of sulfate ${ }^{19,23}$ into sialomucin-like ligands for lymphocyte L-selectin. ${ }^{20,21}$ This step requires prior sulfate activation by PAPS synthetase, a bifunctional enzyme, which utilizes two molecules of ATP for the synthesis of each molecule of PAPS, the high-energy donor of sulfate. ${ }^{22}$ Therefore, preferential expression in HEVECs of mitochondrial proteins, cytochrome $c$ oxidase subunit 1 and cytochrome $b$ (two key components of the ATPsynthesis machinery), might serve to prevent limitation of sulfation (or other biosynthetic activities) by the ATP supply to PAPS synthetase (or other enzymes). Up-regulation of mitochondrial proteins in HEVECs, compared to HUVECs, could also be related to the observation that HEVECs, in situ, contain numerous mitochondria closely associated with the rough endoplasmic reticulum and Golgi complex, a feature generally not seen in ECs from other vessels. ${ }^{16}$

The intense metabolic activity of HEVECs is likely to be linked to the recruitment of a large number of lymphocytes circulating in the blood. ${ }^{11}$ HEVECs are known to secrete high levels of molecules important for lymphocyte migration. These molecules include the sulfated, fucosylated, and sialylated mucin-like ligand for L-selectin, GlyCAM $-1,{ }^{27}$ the chemokine SLC/6Ckine, which mediates rapid activation of lymphocyte adhesiveness, ${ }^{28}$ and the antiadhesive matricellular protein hevin, which may facilitate lymphocyte emigration by weakening EC-to-EC and 
EC-to-matrix adhesion. ${ }^{29,30}$ Our present results suggest that matricellular proteins are major secretory products of HEVECs. In addition to hevin, two other proteins of this family, mac25/IGFB-rP1 and TSP-1, have been identified as preferentially expressed in HEVECs. Similarly to hevin, TSP-1 has been shown to modulate the adhesion of ECs to the ECM and substratum by inhibiting cell spreading and formation of stable cell-substrate adhesion plaques or focal adhesions. ${ }^{41,55} \mathrm{ECs}$ attach to TSP-1 substrates but do not spread, suggesting that TSP-1 can provide an ECM that does not anchor ECs too tightly. Elevated expression in HEVECs of TSP-1 and hevin, two matricellular proteins with adhesion-modulating properties, may constitute one of the properties of the HEV endothelium that allows lymphocyte emigration in HEVs to be so efficient. Hevin, which accumulates on the basolateral and luminal sides of HEVEC membranes, may facilitate lymphocyte migration through endothelial cell junctions, whereas TSP-1, which is associated with the basement membranes (Figure 3), may play an important role in lymphocyte crossing of the HEV basal lamina by weakening EC attachment to adhesive ECM proteins, such as fibronectin, laminin, and collagen IV. In addition, high levels of hevin and TSP-1 may also contribute to the differentiated phenotype of the HEVECs. It is well known that differentiation of ECs, in vitro, can be influenced by the composition of the ECM on which the cells are grown and that ECM-induced cell differentiation can result in profound changes in cell shape. ${ }^{11,41}$ Hevin and TSP-1, which have been shown to modulate EC shape by promoting a rounded morphology in ECs cultured in vitro, ${ }^{30,55}$ may play a role, either directly or indirectly, in the induction of the plump morphology in HEVECs. In addition to its putative role in the induction of this phenotype, TSP-1 may also play a role in the maintenance of the quiescent differentiated state of the HEV endothelium, because TSP-1 has been found to be a potent inhibitor of angiogenesis, ${ }^{56}$ which helps to maintain the differentiated phenotype of endothelial cells in the face of angiogenic stimuli. ${ }^{57} \mathrm{~A}$ major objective of our future studies will be to confirm these proposed roles of TSP-1, hevin, DARC, and mac25/IGFBP-rP1 in the control of lymphocyte migration through HEVs.

\section{Acknowledgments}

We are grateful to Dr. Ron G. Rosenfeld (Portland, OR), Dr. Richard Horuk (Richmond, CA), and Dr. Eugene Butcher (Stanford, CA) for their generous gift of antimac25/IGFBP-rP1 polyclonal antibodies and monoclonal antibodies Fy6 and MECA-79, respectively. Special thanks to Jacques Féliu for DNA sequencing and Yvette de Préval for oligonucleotide synthesis. Prof. Finn P. Reinholt and Ms. Aileen Murdoch Larsen (Laboratory for Electron Microscopy, Department of Pathology, The National Hospital, Norway) are acknowledged for their excellent assistance with the electron microscopy.

\section{References}

1. Simionescu M, Simionescu N, Palade GE: Segmental differentiations of cell junctions in the vascular endothelium. The microvasculature. J Cell Biol 1975, 67:863-885

2. Risau W: Differentiation of endothelium. FASEB J 1995, 9:926-933

3. Garlanda C, Dejana E: Heterogeneity of endothelial cells. Specific markers. Arterioscler Thromb Vasc Biol 1997, 17:1193-1202

4. Cines DB, Pollak ES, Buck CA, Loscalzo J, Zimmerman GA, McEver RP, Pober JS, Wick TM, Konkle BA, Schwartz BS, Barnathan ES, McCrae KR, Hug BA, Schmidt AM, Stern DM: Endothelial cells in physiology and in the pathophysiology of vascular disorders. Blood 1998, 91:3527-3561

5. Augustin HG, Kozian DH, Johnson RC: Differentiation of endothelial cells: analysis of the constitutive and activated endothelial cell phenotypes. Bioessays 1994, 16:901-906

6. Rajotte D, Arap W, Hagedorn M, Koivunen E, Pasqualini R, Ruoslaht $\mathrm{E}$ : Molecular heterogeneity of the vascular endothelium revealed by in vivo phage display. J Clin Invest 1998, 102:430-437

7. Pasqualini R, Ruoslahti E: Organ targeting in vivo using phage display peptide libraries. Nature 1996, 380:364-366

8. Turner RR, Beckstead JH, Warnke RA, Wood GS: Endothelial cell phenotypic diversity. In situ demonstration of immunologic and enzymatic heterogeneity that correlates with specific morphologic subtypes. Am J Clin Pathol 1987, 87:569-575

9. Page C, Rose M, Yacoub M, Pigott R: Antigenic heterogeneity of vascular endothelium. Am J Pathol 1992, 141:673-683

10. Wang HU, Chen ZF, Anderson DJ: Molecular distinction and angiogenic interaction between embryonic arteries and veins revealed by ephrin-B2 and its receptor Eph-B4. Cell 1998, 93:741-753

11. Girard JP, Springer TA: High endothelial venules (HEVs): specialized endothelium for lymphocyte migration. Immunol Today 1995, 16:449457

12. Marchesi VT, Gowans JL: The migration of lymphocytes through the endothelium of venules in lymph nodes: an electron microscopic study. Proc R Soc Lond B 1964, 159:283-290

13. Anderson AO, Anderson ND: Lymphocyte emigration from high endothelial venules in rat lymph nodes. Immunology 1976, 31:731-748

14. Kraal G, Mebius RE: High endothelial venules: Iymphocyte traffic control and controlled traffic. Adv Immunol 1997, 65:347-395

15. Butcher EC, Picker LJ: Lymphocyte homing and homeostasis. Science 1996, 272:60-66

16. Anderson ND, Anderson AO, Wyllie RG: Specialized structure and metabolic activities of high endothelial venules in rat lymphatic tissues. Immunology 1976, 31:455-473

17. Wenk EJ, Orlic D, Reith EJ, Rhodin JA: The ultrastructure of mouse lymph node venules and the passage of lymphocytes across their walls. J Ultrastruct Res 1974, 47:214-241

18. Freemont AJ, Jones CJ: Light microscopic, histochemical and ultrastructural studies of human lymph node paracortical venules. J Anat 1983, 136:349-362

19. Andrews P, Milsom DW, Ford WL: Migration of lymphocytes across specialized vascular endothelium. V. Production of a sulphated macromolecule by high endothelial cells in lymph nodes. J Cell Sci 1982, 57:277-292

20. Imai Y, Lasky LA, Rosen SD: Sulphation requirement for GlyCAM-1, an endothelial ligand for L-selectin. Nature 1993, 361:555-557

21. Hemmerich S, Butcher EC, Rosen SD: Sulfation-dependent recognition of high endothelial venules (HEV)-ligands by L-selectin and MECA 79, and adhesion-blocking monoclonal antibody. J Exp Med 1994, 180:2219-2226

22. Girard JP, Baekkevold ES, Amalric F: Sulfation in high endothelial venules: cloning and expression of the human PAPS synthetase. FASEB J 1998, 12:603-612

23. Girard JP, Amalric F: Biosynthesis of sulfated L-selectin ligands in human high endothelial venules (HEV). Adv Exp Med Biol 1998, 435:55-62

24. Streeter PR, Rouse BT, Butcher EC: Immunohistologic and functional characterization of a vascular addressin involved in lymphocyte homing into peripheral lymph nodes. J Cell Biol 1988, 107:1853-1862

25. Michie SA, Streeter PR, Bolt PA, Butcher EC, Picker LJ: The human peripheral lymph node vascular addressin. An inducible endothelial antigen involved in lymphocyte homing. Am J Pathol 1993, 143:16881698 
26. Uchimura K, Muramatsu H, Kadomatsu K, Fan QW, Kurosawa N, Mitsuoka C, Kannagi R, Habuchi O, Muramatsu T: Molecular cloning and characterization of an N-acetylglucosamine-6-O-sulfotransferase. J Biol Chem 1998, 273:22577-22583

27. Lasky LA, Singer MS, Dowbenko D, Imai Y, Henzel WJ, Grimley C, Fennie C, Gillett N, Watson SR, Rosen SD: An endothelial ligand for L-selectin is a novel mucin-like molecule. Cell 1992, 69:927-938

28. Gunn MD, Tangemann K, Tam C, Cyster JG, Rosen SD, Williams LT: A chemokine expressed in lymphoid high endothelial venules promotes the adhesion and chemotaxis of naive $T$ lymphocytes. Proc Natl Acad Sci USA 1998, 95:258-263

29. Girard JP, Springer TA: Cloning from purified high endothelial venule cells of hevin, a close relative of the antiadhesive extracellular matrix protein SPARC. Immunity 1995, 2:113-123

30. Girard JP, Springer TA: Modulation of endothelial cell adhesion by hevin, an acidic protein associated with high endothelial venules. J Biol Chem 1996, 271:4511-4517

31. Mebius RE, Bauer J, Twisk AJ, Breve J, Kraal G: The functional activity of high endothelial venules: a role for the subcapsular sinus macrophages in the lymph node. Immunobiology 1991, 182:277-291

32. Baekkevold ES, Jahnsen FL, Johansen FE, Bakke O, Gaudernack G Brandtzaeg P, Haraldsen G: Culture characterization of differentiated high endothelial venule cells from human tonsils. Lab Invest 1999 79:327-336

33. Diatchenko L, Lau YF, Campbell AP, Chenchik A, Moqadam F, Huang B, Lukyanov S, Lukyanov K, Gurskaya N, Sverdlov ED, Siebert PD: Suppression subtractive hybridization: a method for generating differentially regulated or tissue-specific cDNA probes and libraries. Proc Natl Acad Sci USA 1996, 93:6025-6030

34. Akaogi K, Okabe Y, Sato J, Nagashima Y, Yasumitsu H, Sugahara K, Miyazaki K: Specific accumulation of tumor-derived adhesion factor in tumor blood vessels and in capillary tube-like structures of cultured vascular endothelial cells. Proc Natl Acad Sci USA 1996, 93:83848389

35. Oh Y, Nagalla SR, Yamanaka Y, Kim HS, Wilson E, Rosenfeld RG: Synthesis and characterization of insulin-like growth factor-binding protein (IGFBP)-7. Recombinant human mac25 protein specifically binds IGF-I and -II. J Biol Chem 1996, 271:30322-30325

36. Altschul SF, Gish W, Miller W, Myers EW, Lipman DJ: Basic local alignment search tool. J Mol Biol 1990, 215:403-410

37. Thompson JD, Higgins DG, Gibson TJ: CLUSTAL W: improving the sensitivity of progressive multiple sequence alignment through sequence weighting, position-specific gap penalties and weight matrix choice. Nucleic Acids Res 1994, 22:4673-4680

38. Chu W, Presky DH, Swerlick RA, Burns DK: Alternatively processed human E-selectin transcripts linked to chronic expression of E-selectin in vivo. J Immunol 1994, 153:4179-4189

39. Attardi G, Schatz G: Biogenesis of mitochondria. Annu Rev Cell Biol $1988,4: 289-333$

40. Bornstein P: Diversity of function is inherent in matricellular proteins: an appraisal of thrombospondin 1. J Cell Biol 1995, 130:503-506

41. Sage EH, Bornstein P: Extracellular proteins that modulate cell-matrix interactions. SPARC, tenascin, and thrombospondin. J Biol Chem 1991, 266:14831-14834

42. Hadley TJ, Peiper SC: From malaria to chemokine receptor: the emerging physiologic role of the Duffy blood group antigen. Blood 1997, 89:3077-3091
43. Neote K, Mak JY, Kolakowski LF, Jr, Schall TJ: Functional and biochemical analysis of the cloned Duffy antigen: identity with the red blood cell chemokine receptor. Blood 1994, 84:44-52

44. Hadley TJ, Lu ZH, Wasniowska K, Martin AW, Peiper SC, Hesselgesser J, Horuk R: Postcapillary venule endothelial cells in kidney express a multispecific chemokine receptor that is structurally and functionally identical to the erythroid isoform, which is the Duffy blood group antigen. J Clin Invest 1994, 94:985-991

45. Peiper SC, Wang ZX, Neote K, Martin AW, Showell HJ, Conklyn MJ, Ogborne K, Hadley TJ, Lu ZH, Hesselgesser J, Horuk R: The Duffy antigen/receptor for chemokines (DARC) is expressed in endothelial cells of Duffy negative individuals who lack the erythrocyte receptor. J Exp Med 1995, 181:1311-1317

46. Maly P, Thall A, Petryniak B, Rogers CE, Smith PL, Marks RM, Kelly RJ, Gersten KM, Cheng G, Saunders TL, Camper SA, Camphausen RT, Sullivan FX, Isogai Y, Hindsgaul O, von Andrian UH, Lowe JB: The $\alpha(1,3)$ fucosyltransferase Fuc-TVII controls leukocyte trafficking through an essential role in L-, E-, and P-selectin ligand biosynthesis. Cell 1996, 86:643-653

47. Schaniel C, Pardali E, Sallusto F, Speletas M, Ruedl C, Shimizu T, Seidl T, Andersson J, Melchers F, Rolink AG, Sideras P: Activated murine B lymphocytes and dendritic cells produce a novel CC chemokine which acts selectively on activated T cells. J Exp Med 1998 188:451-463

48. Mueller CG, Rissoan MC, Salinas B, Ait-Yahia S, Ravel O, Bridon JM, Briere F, Lebecque S, Liu YJ: Polymerase chain reaction selects a novel disintegrin proteinase from CD40-activated germinal center dendritic cells. J Exp Med 1997, 186:655-663

49. Middleton J, Neil S, Wintle J, Clark-Lewis I, Moore H, Lam C, Auer M Hub E, Rot A: Transcytosis and surface presentation of IL-8 by venular endothelial cells. Cell 1997, 91:385-395

50. Murphy M, Pykett MJ, Harnish P, Zang KD, George DL: Identification and characterization of genes differentially expressed in meningiomas. Cell Growth Differ 1993, 4:715-722

51. Swisshelm K, Ryan K, Tsuchiya K, Sager R: Enhanced expression of an insulin growth factor-like binding protein (mac25) in senescent human mammary epithelial cells and induced expression with retinoic acid. Proc Natl Acad Sci USA 1995, 92:4472-4476

52. Yamauchi T, Umeda F, Masakado M, Isaji M, Mizushima S, Nawata H: Purification and molecular cloning of prostacyclin-stimulating factor from serum-free conditioned medium of human diploid fibroblast cells. Biochem J 1994, 303:591-598

53. Fina L, Molgaard HV, Robertson D, Bradley NJ, Monaghan $P$, Delia D Sutherland DR, Baker MA, Greaves MF: Expression of the CD34 gene in vascular endothelial cells. Blood 1990, 75:2417-2426

54. Kikuta A, Rosen SD: Localization of ligands for L-selectin in mouse peripheral lymph node high endothelial cells by colloidal gold conjugates. Blood 1994, 84:3766-3775

55. Murphy-Ullrich JE, Hook M: Thrombospondin modulates focal adhesions in endothelial cells. J Cell Biol 1989, 109:1309-1319

56. Dameron KM, Volpert OV, Tainsky MA, Bouck N: Control of angiogenesis in fibroblasts by p53 regulation of thrombospondin-1. Science 1994, 265:1582-1584

57. Sheibani N, Frazier WA: Thrombospondin 1 expression in transformed endothelial cells restores a normal phenotype, and suppresses their tumorigenesis. Proc Natl Acad Sci USA 1995, 92:67886792 